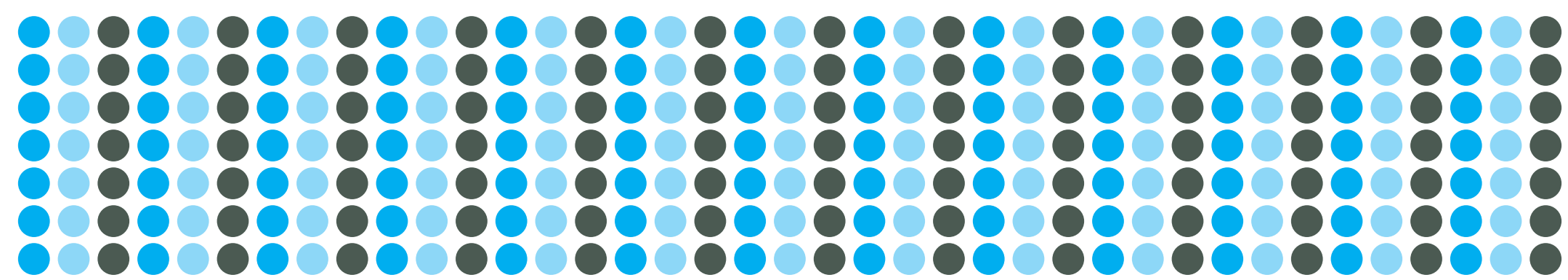

AUTHOR BIOGRAPHIES
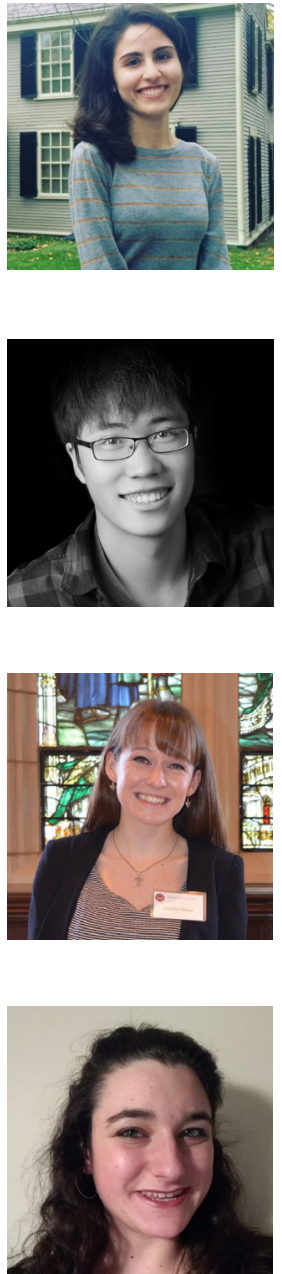

\title{
JULIANA BUTRON
}

Before coming to Boston College, Juliana studied visual arts at Fiorello LaGuardia, a public arts school, in New York City. Growing up in a diverse Brooklyn neighborhood exposed her to different points of view. This environment taught her that there are many sides to every story. As a result, she has developed a fondness for exploring timely issues in unique ways. This semester, she is excited to continue her role as a co-facilitator for the Thea Bowman AHANA and Intercultural Center's Dialogues on Race. After graduation, she hopes to pursue a master's degree in American Government.

\section{ARTHUR DIEP-NGUYEN}

is a sophomore at Boston College from San Marino, California. While originally a Biology major, Arthur discovered a passion for mathematics during the fall semester of his freshman year, when his Calculus II professor Igor Minevich introduced him to various proofs, puzzles, and other topics in math. This initial experience spurred Arthur to expand his academic horizons. Since then, Arthur has worked on math research with classmates and continues to pursue his interests in both science and math. Currently a Biochemistry and Mathematics double major, Arthur is also a trombonist in the University Wind Ensemble and in the bOp! Jazz Ensemble.

\section{JENNIFER HEINE}

is currently a senior in the Morrissey Arts and Sciences Honors Program at Boston College with a double major in English and Hispanic Studies and a minor in Creative Writing. A Dean's List student and a member of the Order of the Cross and Crown Honor Society, she plans to pursue graduate studies in comparative literature. Jennifer has been a member of the Dickens Fellowship since 2010, and her most recent research involves comparing the work of Dickens work to that of Cervantes and other picaresque writers. A fluent Spanish speaker, she studied at the Universidad Complutense in Madrid. In addition to her academic studies, she enjoys writing creatively, both editing and contributing to the Stylus.

\section{KATELYN JOHNSON}

is currently a senior in the Morrissey College of Arts and Sciences, majoring in Biochemistry and minoring in History. During the Summer of 2015, she took part in the Interdisciplinary Water Sciences and Engineering NSF REU program at Virginia Polytechnic Institute and State University. Working with Dr. Kang Xia and Ph.D. student Hanh Le, she completed research in a surface stream concerning neonicotinoid transport and transformation. Currently, her research comprises of deicer contaminant transport in the Charles River Watershed under the advisement of Dr. Rudolph Hon and Dr. James Besancon. After graduation, Katelyn plans on pursuing a Master's degree in Civil Engineering, with a focus on Water Resources. When she is not conducting research, you can find her playing her Baritone in the Boston College Marching Band, singing in the University Chorale, advising Venture Scouts, and leading students as the co-president of BC's student organization STITCH. 

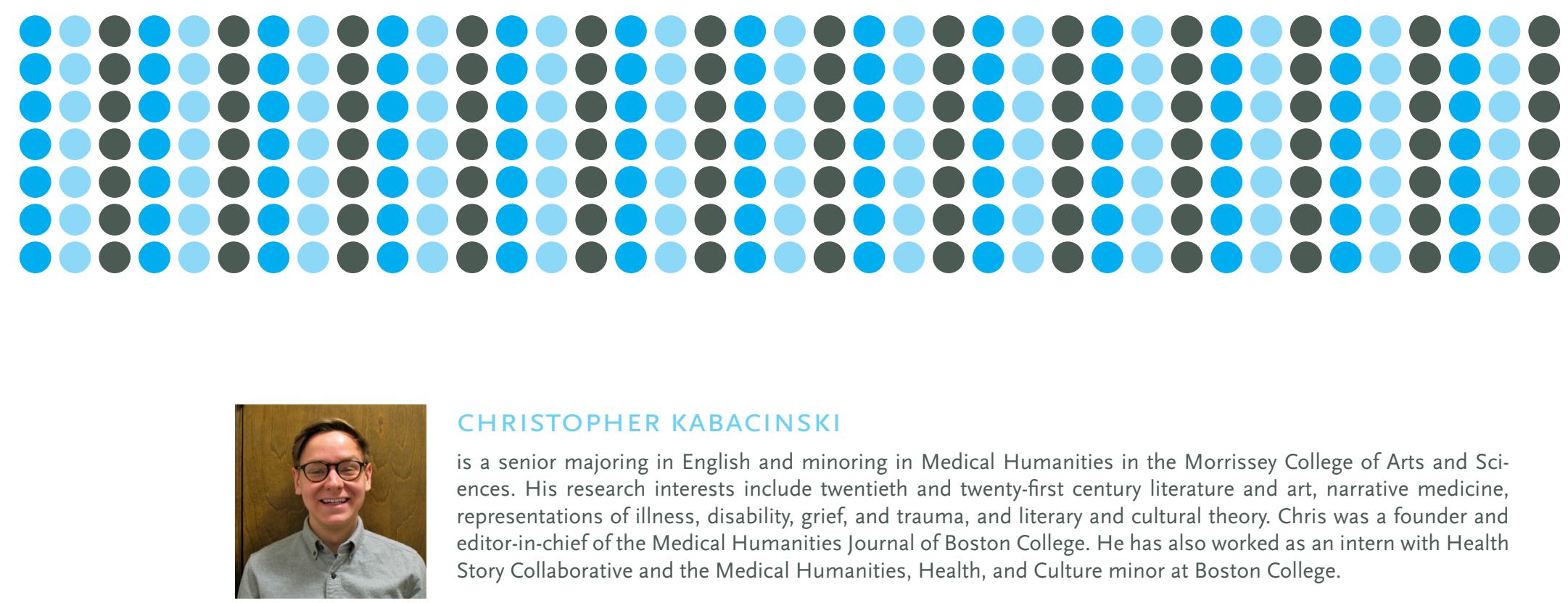

\section{CHRISTOPHER KABACINSKI}

is a senior majoring in English and minoring in Medical Humanities in the Morrissey College of Arts and Sciences. His research interests include twentieth and twenty-first century literature and art, narrative medicine, representations of illness, disability, grief, and trauma, and literary and cultural theory. Chris was a founder and editor-in-chief of the Medical Humanities Journal of Boston College. He has also worked as an intern with Health Story Collaborative and the Medical Humanities, Health, and Culture minor at Boston College.

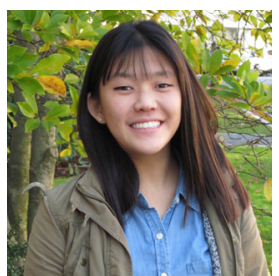

\section{YOON-SHIN (CLARA) LEE}

is a junior studying Applied Psychology and Human Development and Sociology in the Lynch School of Education. She is originally from San Jose, California, but graduated high school in South Korea. She is currently in the Lynch Honors Programs and Sociology departmental honors. On campus, she is involved in UGBC, the Student Admissions Program, and various intercultural organizations. In her spare time, Clara also works in the Memory, Metacognition, and Learning Lab as a research fellow and volunteers at Boston Children's Hospital. After graduation, she hopes to attend graduate school and pursue a career in social justice and/or education.

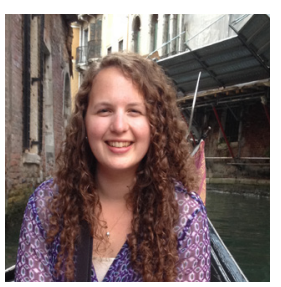

\section{ALESSANDRA LUEDEKING}

is a junior in the Morrissey College of Arts and Sciences double majoring in English and International Studies with a concentration in ethics and international social justice. After completing her undergraduate degree, she hopes to volunteer with the Jesuit Volunteer Corps in a two-year international program aimed at addressing social injustice and pursuing sustainable development in impoverished nations. She would like to teach English as a second language abroad, and then return to America to earn a master's degree and work for the United Nations. She is a member of the Christian a cappella group, Against The Current, and the Deputy Editor for Elements.

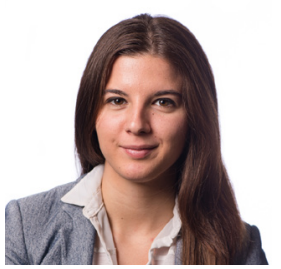

\section{REBECCA MORETTI}

is a junior in the Political Science Honors Program at Boston College. She was born in Los Angeles, but lived in Rome until the age of eight, before moving back to the United States, where she attended Harvard-Westlake school. She is interested in international security and diplomacy, and is fluent in five languages. At Boston College, Rebecca is a John Marshall Fellow and a staff writer for The Heights. Rebecca is passionate about writing and film and has published several plays that have been performed around the country. She is currently studying abroad at the University College London in the department of Political Science. 

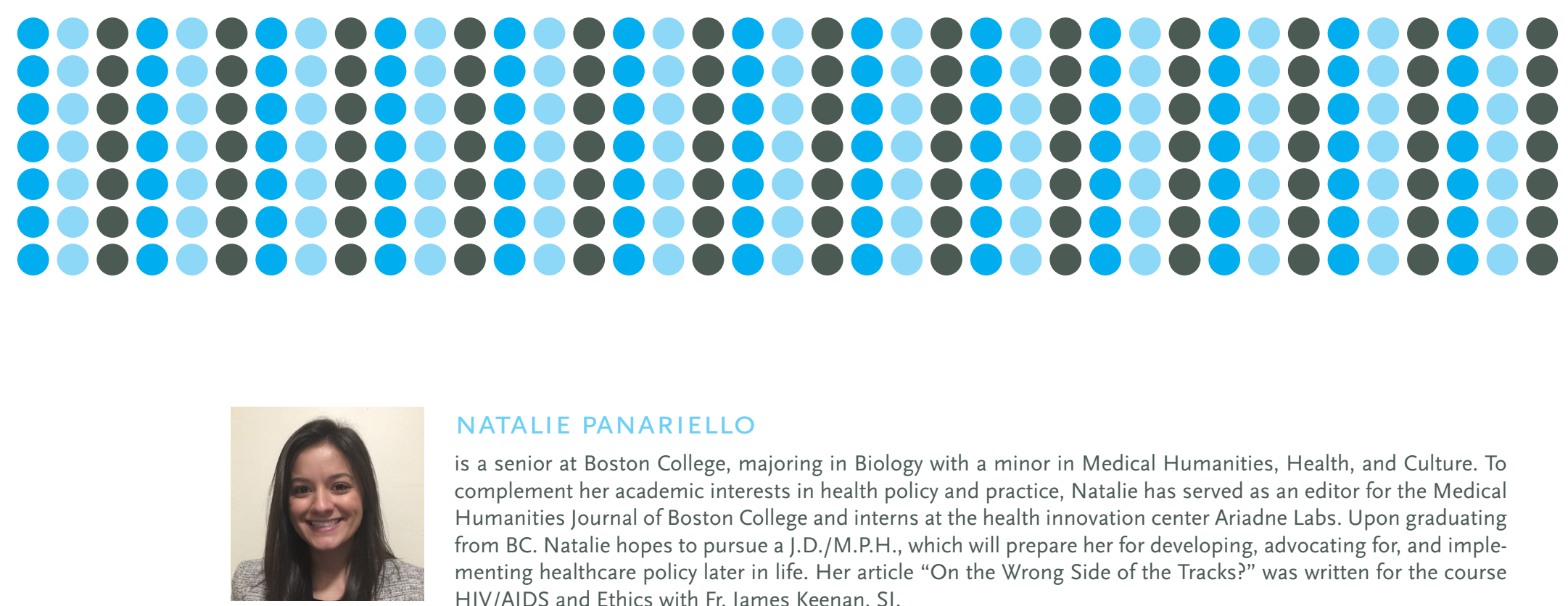

\section{NATALIE PANARIELLO}

is a senior at Boston College, majoring in Biology with a minor in Medical Humanities, Health, and Culture. To complement her academic interests in health policy and practice, Natalie has served as an editor for the Medical Humanities Journal of Boston College and interns at the health innovation center Ariadne Labs. Upon graduating from BC. Natalie hopes to pursue a J.D./M.P.H., which will prepare her for developing, advocating for, and implementing healthcare policy later in life. Her article "On the Wrong Side of the Tracks?" was written for the course HIV/AIDS and Ethics with Fr. James Keenan, SJ.

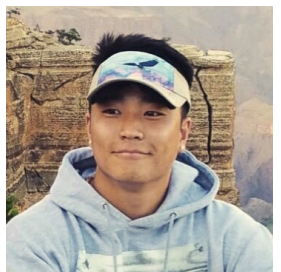

\section{DANIEL PARK}

is a senior in the Morrisey College of Arts and Sciences majoring in International Studies. He was born in Los Angeles, lived in Israel, but now lives in Boston. After graduation, Dan is planning to attend graduate school to study international development to become a developmental consultant, while also working in corporate finance for a healthcare company during graduate school. In his free time, Dan enjoys spending time with friends and family, playing and watching sports, and making dumb jokes he thinks are funny.

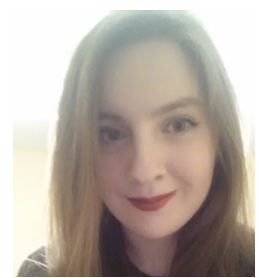

\section{KATHERINE QUIGLEY}

is a senior in the Morrissey College of Arts and Sciences. She is majoring in History and minoring in German and Women's and Gender Studies. Last summer, she was awarded a fellowship at Historic Deerfield to study New England history, material culture, and museum studies. She is currently working on a Scholar of the College thesis about crime and gender in the late eighteenth century. After graduation, she plans to attend graduate school in order to work as a curator in a history museum. 


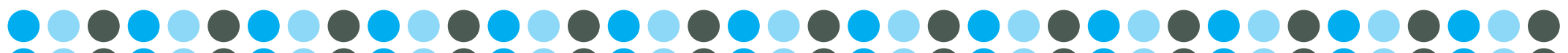

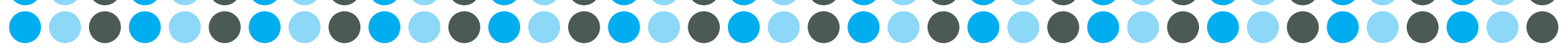

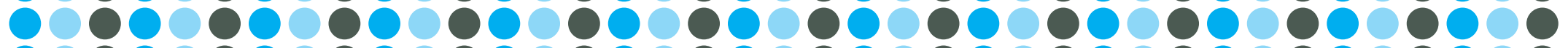

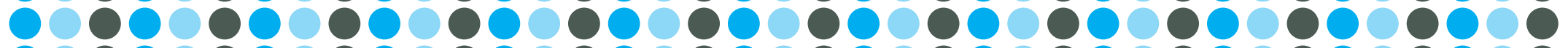

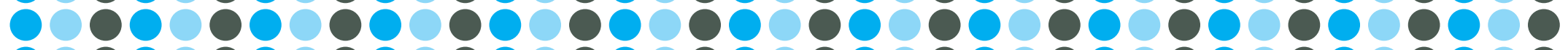

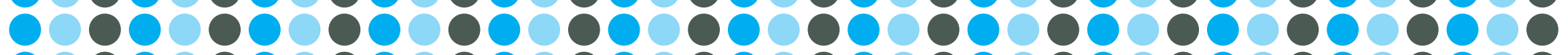

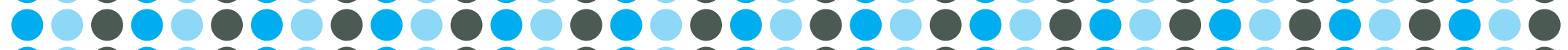

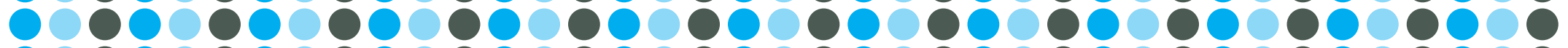

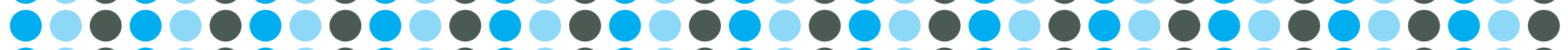

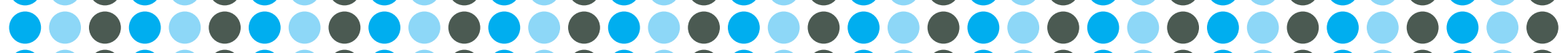

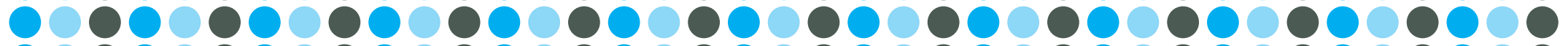

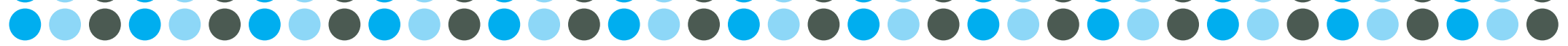

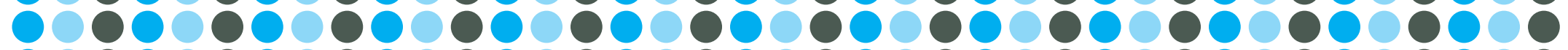

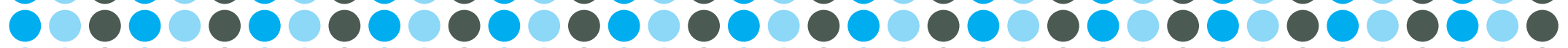

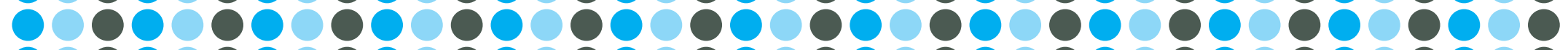

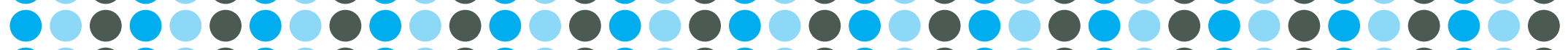

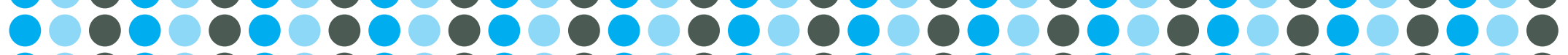

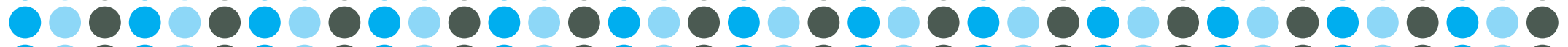

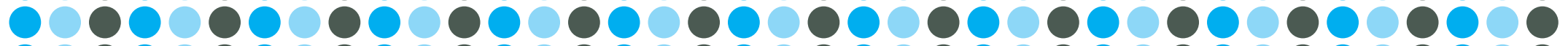

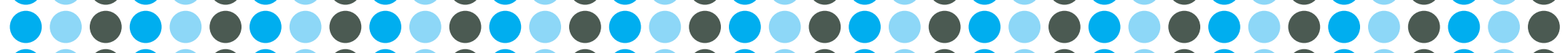

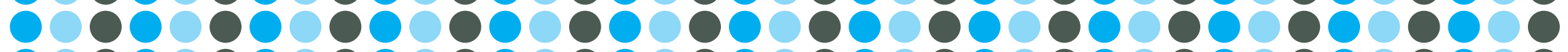

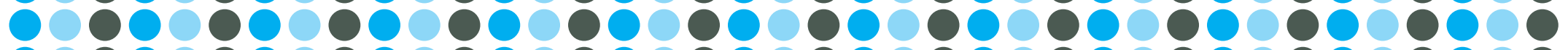

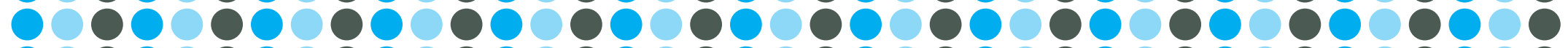

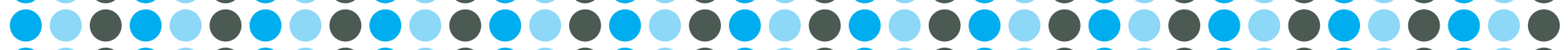

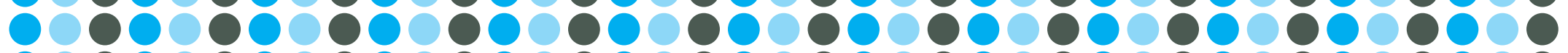

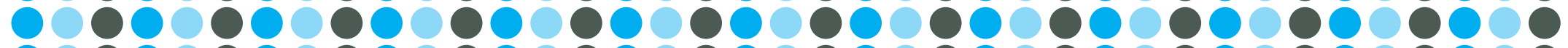

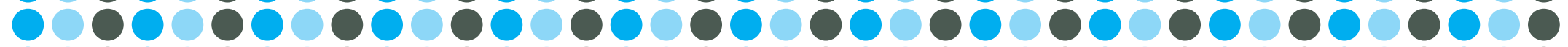

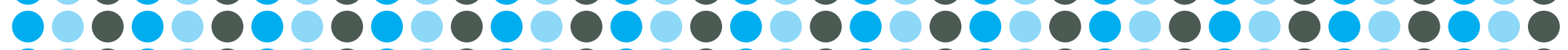

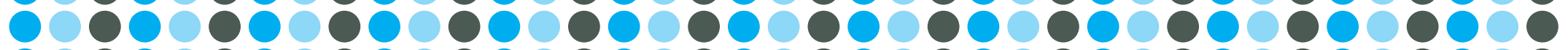

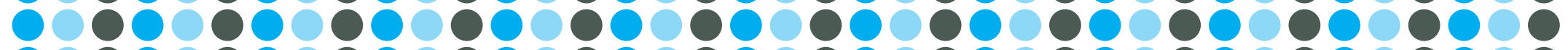

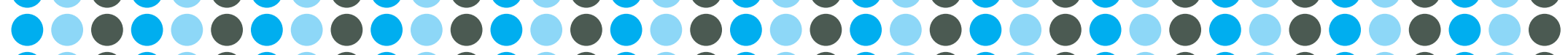

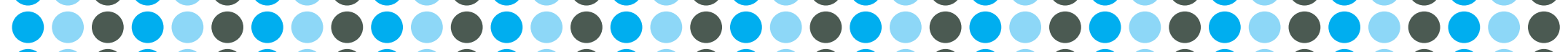

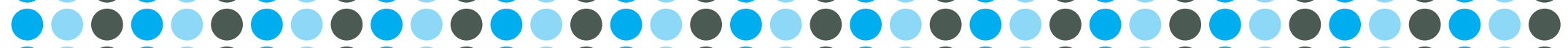

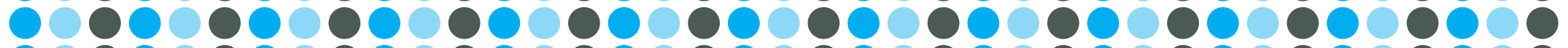

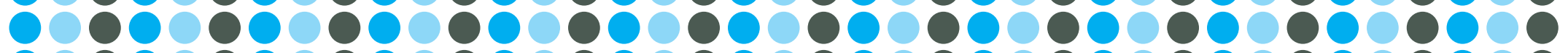

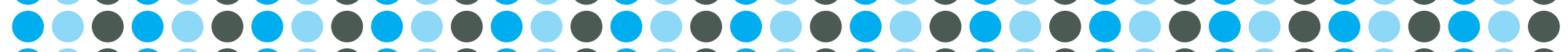

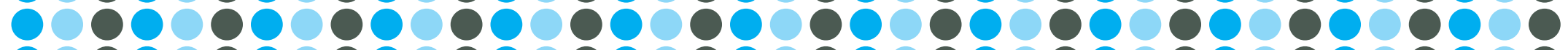

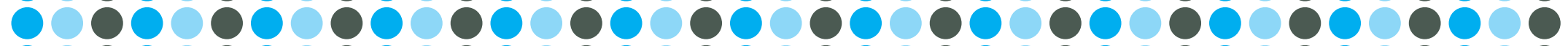

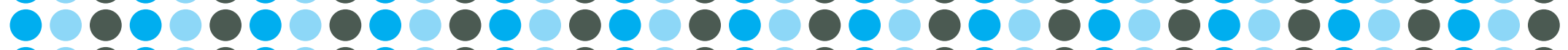

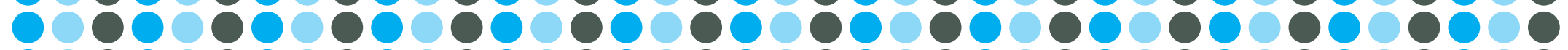

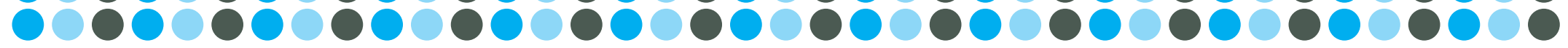




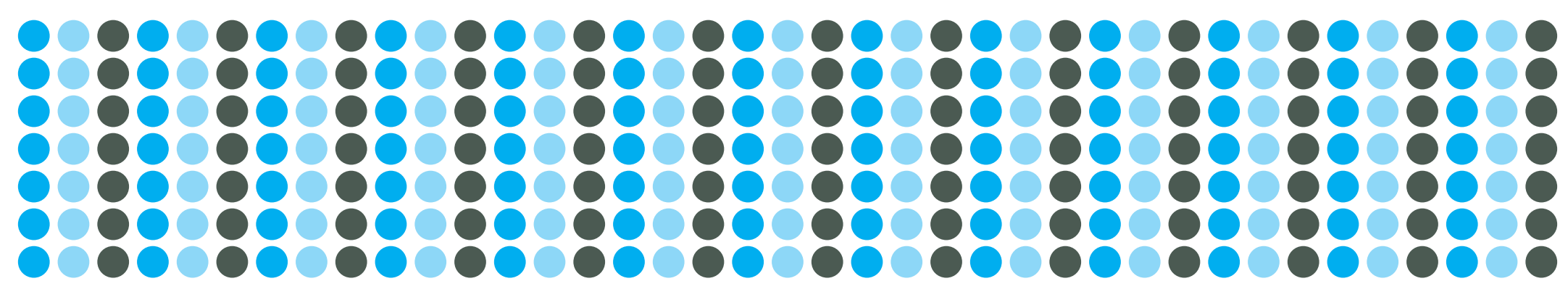

LIST OF ARTWORK

IO CLEAN HYPODERMIC NEEDLES

(C) By The U.S. Food and Drug Administration (Improperly Discarded 'Sharps' Can Be Dangerous) [Public domain], via Wikimedia Commons

I2 MARKET-FRANKFORD LINE

(C) By Dasprevailz (Own work) [Public domain], via Wikimedia Commons

THE OLDEST WOODEN JAIL

(C) Swampyank at English Wikipedia [GFDL (http://www.gnu.org/copyleft/fdl.html) or CC BY- SA 3.0 (http:// creativecommons.org/licenses/by-sa/3.0)], via Wikimedia Commons

IC MAN ON TRIAL

(C) Wikimedia Commons

2. I THE TYBURN GALLOWS

(C) Wikimedia Commons

2 18TH CENTURY TRIAL

(C) Wikimedia Commons

2 I REDWOOD TREE

(C) By User:Jyekrang (Own work) [CC BY-SA 3.0 (http://creativecommons.org/licenses/by- sa/3.o)], via Wikimedia Commons

32 GLOBAL ACTION DAY IN COPENHAGEN

(C) By america.gov.Malte at da.wikipedia [CC BY-SA 2.0 (http://creativecommons.org/licenses/by-sa/2.o)], from Wikimedia Commons

25 GERMAN POLITICIAN DENYING CLIMATE CHANGE

(C) By Gerhard Mester (Solarenergie-Förderverein Deutschland e.V.) [CC BY-SA 4.0 (http://creativecommons. org/licenses/by-sa/4.0)], via Wikimedia Commons

5 TIRESIAS STRIKING A SNAKE

(C) By Krauss, Johann Ulrich, I645-I7I9 (Yale Beinecke Rare Book and Manuscript Library [I]) [Public domain], via Wikimedia Commons

5 T TIRESIAS APPEARING TO ULYSSES

(C) Henry Fuseli [Public domain or Public domain], via Wikimedia Commons 


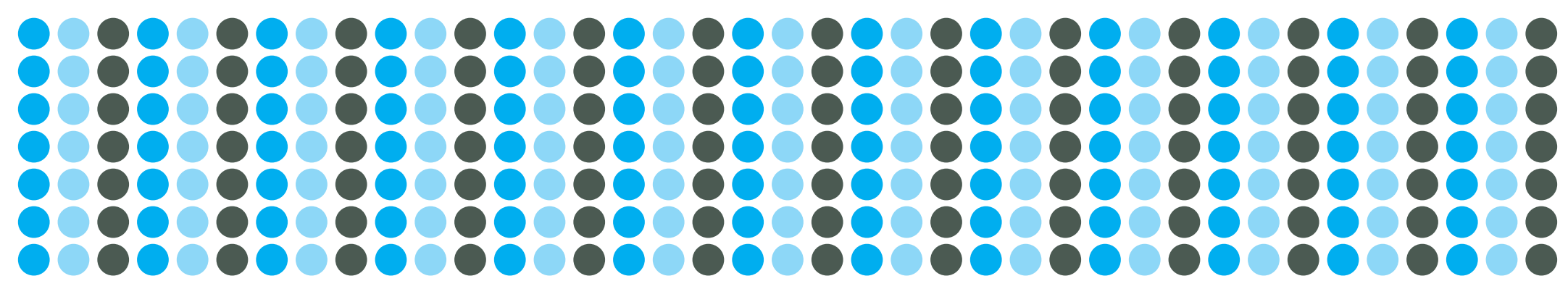

52 OEDIPUS AT COLONUS

(C) Jean-Antoine-Théodore Giroust [Public domain], via Wikimedia Commons

\section{- AN ASSISTANCE DOG}

) (C) By smerikal (https://www.flickr.com/photos/smerikal/5555789969/) [CC BY-SA 2.0 (http://creativecommons.org/licenses/by-sa/2.o)], via Wikimedia Commons ASIAN COLLEGE STUDENTS

(C) By Fernando de Sousa (http://www.flickr.com/photos/fernando/345125130/) [CC BY-SA 2.0 (http://creativecommons.org/licenses/by-sa/2.0)], via Wikimedia Commons

\section{AN AERIAL VIEW OF BOSTON COLLEGE}

(C) By No machine-readable author provided. Yelm assumed (based on copyright claims). [GFDL (http://www. gnu.org/copyleft/fdl.html), CC-BY-SA-3.o (http://creativecommons.org/licenses/by-sa/3.o/) or CC BY-SA 2.0 (http://creativecommons.org/licenses/by-sa/2.o)], via Wikimedia Commons

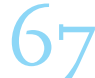

ASIAN COLLEGE STUDENTS IN CLASS

(C) Publicdomainpictures

72 CARL SCHURZ AND UNCLE SAM

(C) Thomas Nast [Public domain], via Wikimedia Commons

73 CARTOON OF NATIONALIST

(C) Rollin Kirby [Public domain], via Wikimedia Commons

76 186OS LONDON

(C) Wikimedia Commons

78 ANTHONY TROLLOPE

(C) Wikimedia Commons

7 MANUSCRIPT OF PHINEAS FINN

(C) Flickr 


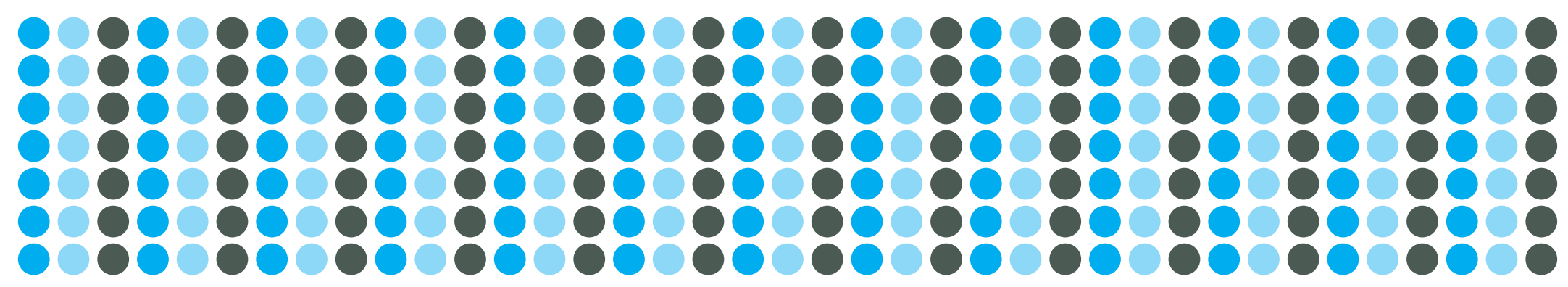

LIST OF ARTWORK

84 MOVIE POSTER

(C) By Toho Company Ltd. (Toho Kabushiki-kaisha), (C I956 [Public domain], via Wikimedia Commons

85 Атоміс вомв

(C) By Charles Levy from one of the B-29 Superfortresses used in the attack. [Public domain], via Wikimedia Commons

86 TREATMENT OF CREW MEMBER

(C)Wikimedia Commons 


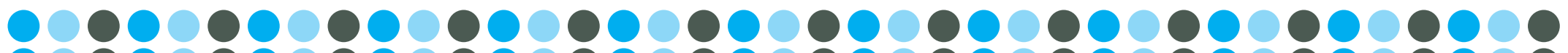

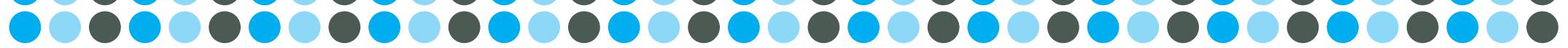

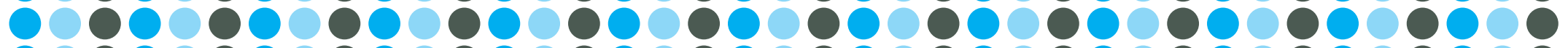

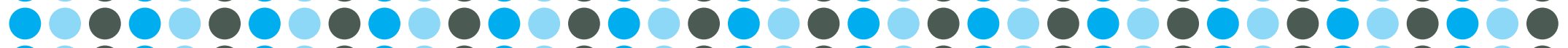

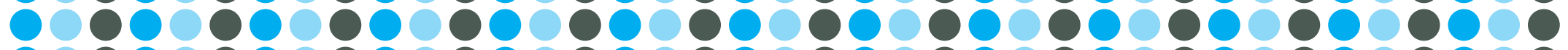

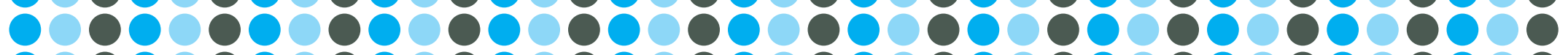

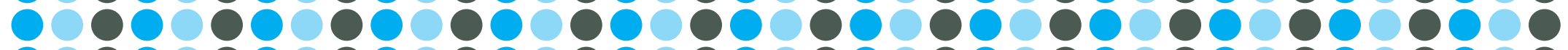

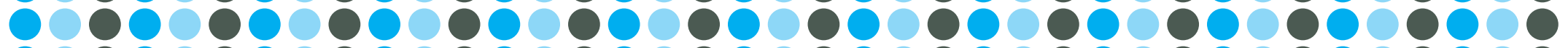

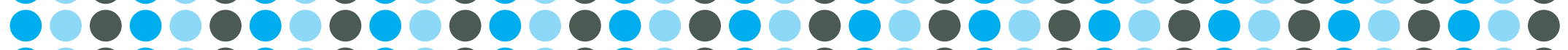

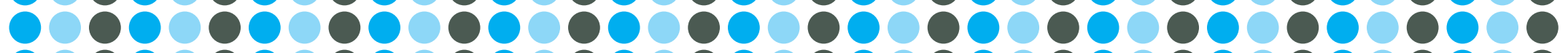

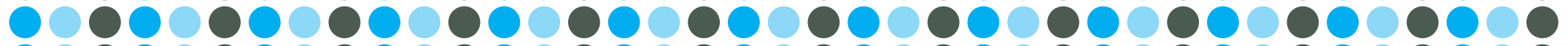

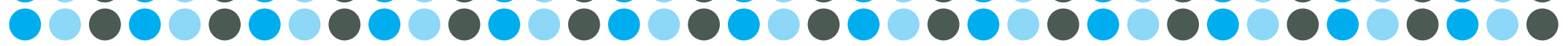

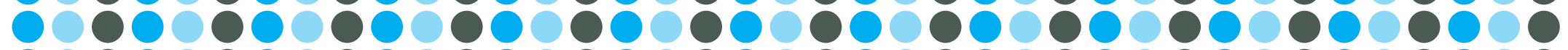

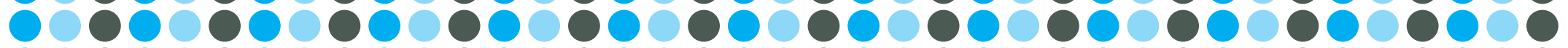

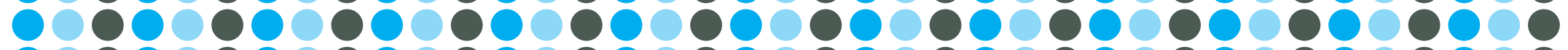

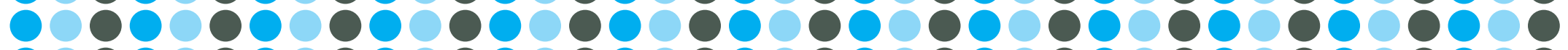

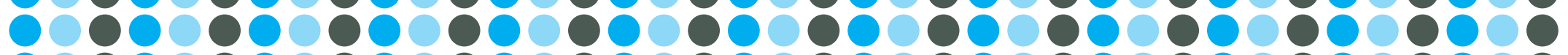

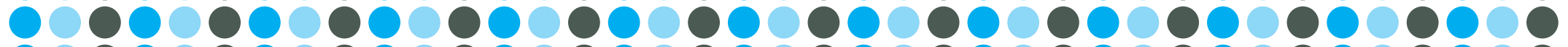

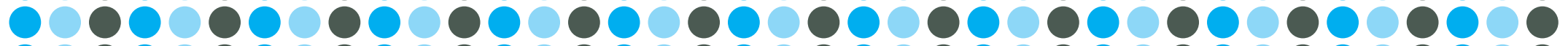

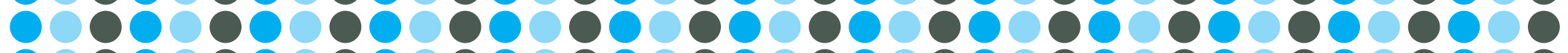

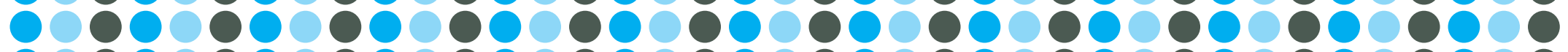

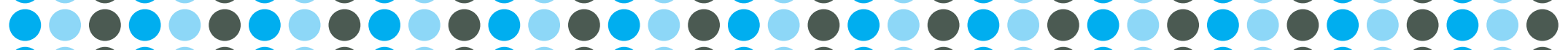

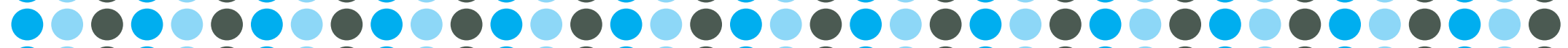

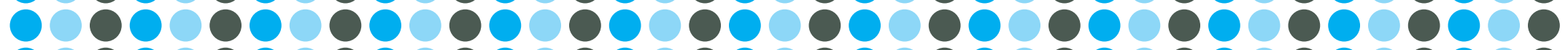

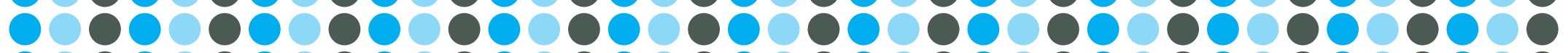

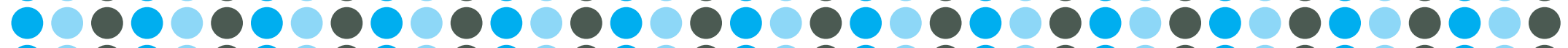

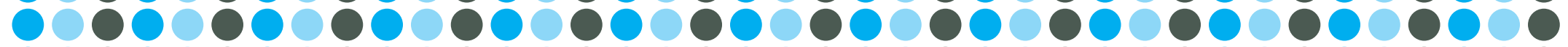

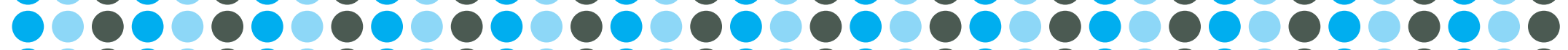

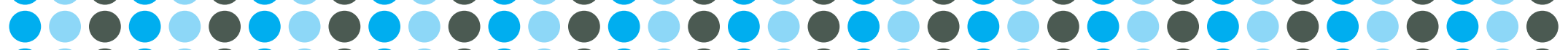

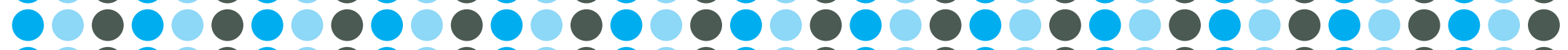

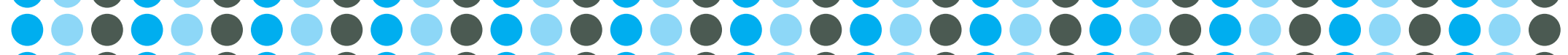

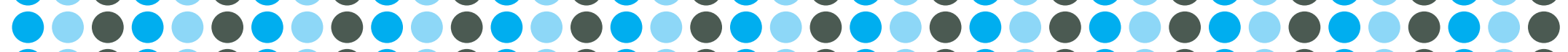

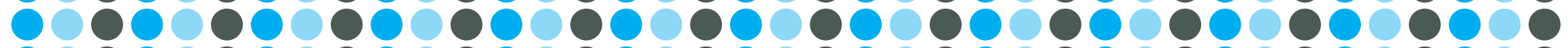

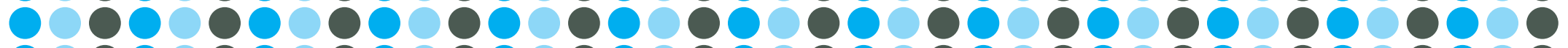

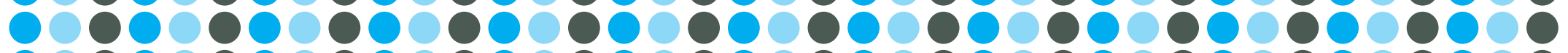

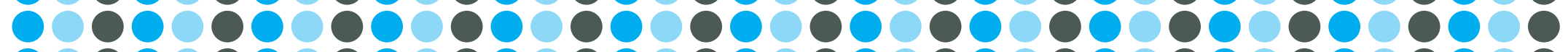

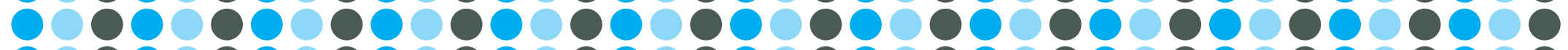

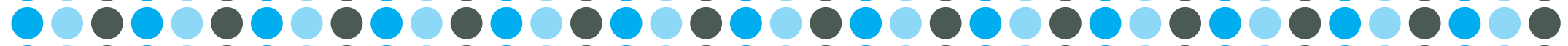

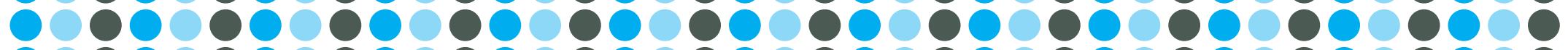

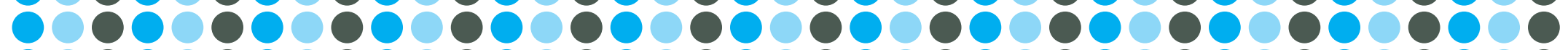

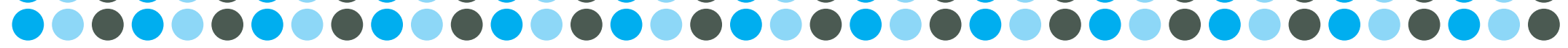




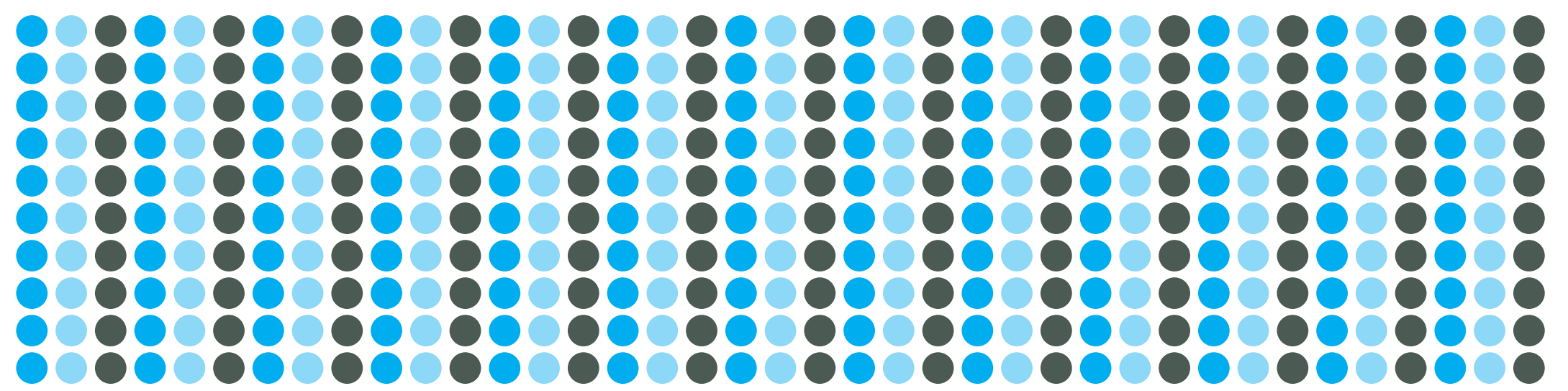




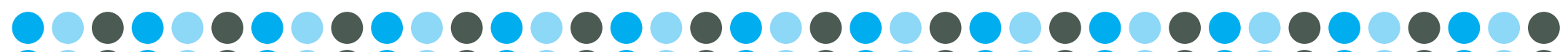
○

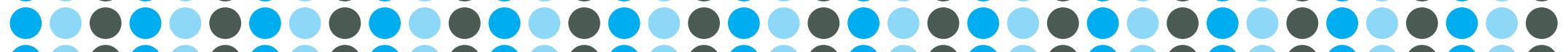

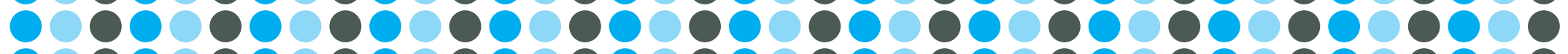

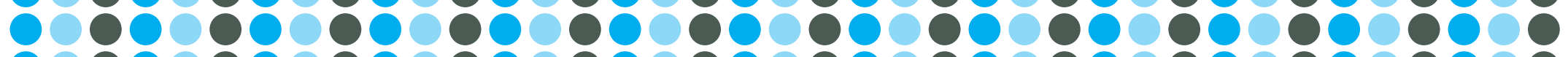

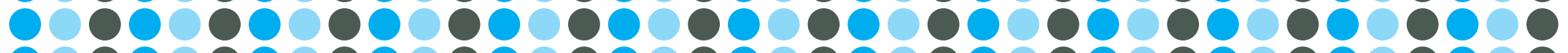

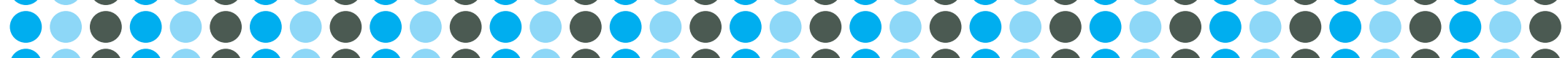

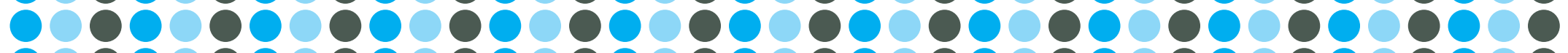

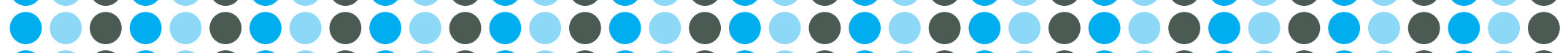
00000000000000000000000000000000000000 


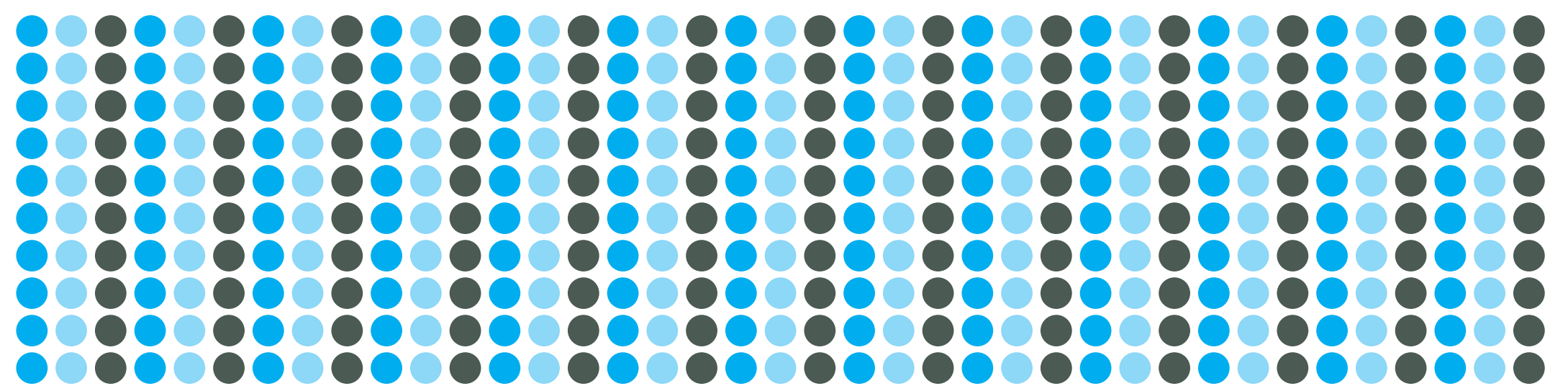




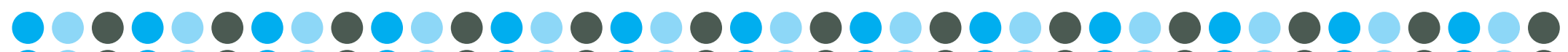
○

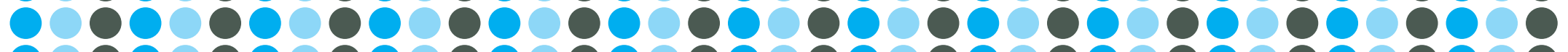

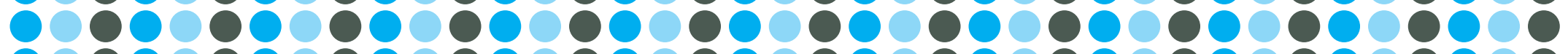

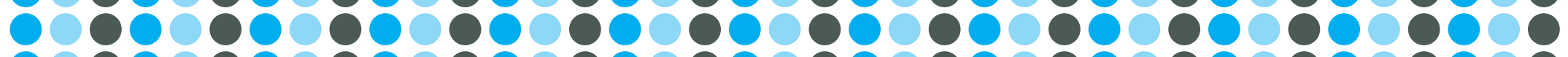

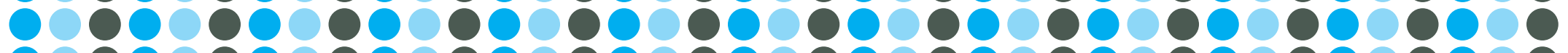

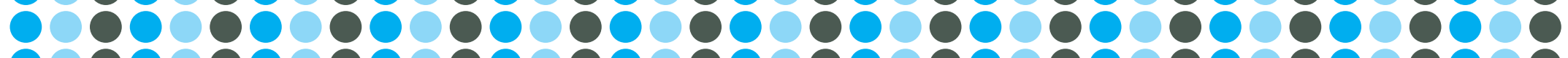

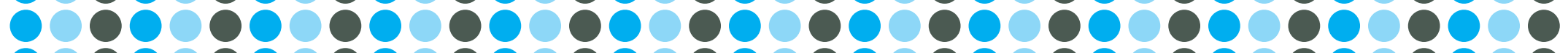

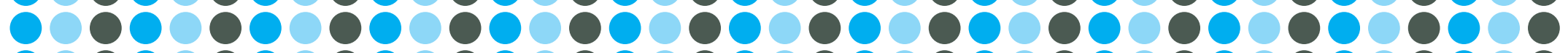
00000000000000000000000000000000000000 